Agnieszka Sojka

Jagiellonian University in Cracow

Anna Szarek

\title{
Modern teachers' responsibilities in the contemporary changing culture. The role of brand personalities in the development of personal identities in adolescents
}

\section{ABSTRACT}

In the contemporary society, teachers are confronted with an exceptional challenge that is different from those of earlier generations. In education, the subject of brand personality is not yet a well-studied field. The authors would like to shed some light on the important phenomenon.

Key words: brand personality, education, pupil-teacher relationship, technological culture, current generation

The following article is a reflection on the role of brand personalities in today's field of education and their consequences on teacher's responsibilities in today's culture of global transformation. The authors come from two different backgrounds. One is an educator and studies alternative education methods specifically using her musical background and research into popular culture, while the other comes from media marketing and public relations. The authors combine both theoretical and practical knowledge from their educational and managerial experiences. Their goal is to synergize their different fields in order to look at brands and marketing from a new perspective. 
In education, the subject of brand personality is not yet a well-known or well-studied field. An American social psychologist, Jennifer L. Aaker, defines brand personality as "the set of human characteristics associated with a brand" (Aaker, 1997). Currently, the concept of brand personalities is a popular phenomenon in business psychology. However, in the near future this will most likely extend to become a field of study not only for business psychology but also for teachers, mentors, educators, coaches, and counselors.

In today's society, teachers are confronted with an exceptional challenge that is different from those of earlier generations. Teachers must follow a mandated curriculum while also addressing the issues of values in modern life with far reaching applications outside of the classroom. Culture and society are changing rapidly in today's world as are values as a consequence of that. Today more than ever, teachers struggle with incorporating and teaching social values associated with new global technologies and modern consumerism while still adhering to their curricula. They struggle with the responsibility of making both of these things important to their students and showing them the place and value of each. Today, students are bombarded with advertisements, pop culture, and media. This technological and consumptive culture becomes a part of their upbringing and this becomes a central feature of the studentteacher relationship. This puts the teacher in a difficult position because if the teachers completely separates themselves from this popular culture at large this can estrange them from the student thereby negating any impact educational or otherwise they may be able to have.

Within the last century the ways in which people absorb media has changed drastically. Today, everything is faster. Newspapers, magazines, and television all have more color, use more noise, and are more and more geared toward individuals and their differing personality types. Different countries and cultures have experienced this change at different times over the last few decades but the resulting cultural transformation is the same. Music, for example used to be a medium that was the same for people of any age. Each culture or country had its own specific style and it was for all ages. Over the last 100 years this has changed drastically as we can see with so the many styles and classifications of music from all over the world that exist today. Many of these styles can be associated with a particular group of people or type of personality. The world of print media has changed in a similar way as well. Most printed language used to be educational, intellectual, and traditional, but with the onset of mass printing at a global scale, magazines and newspapers began to convey new 
concepts. The new trends, styles, and values that the printed word has taken on are somewhat in contrast to older more traditional values. Today's printed media leans heavily toward the idea of individuality and individual choice, each of the many styles appealing to a different kind of person, a different audience. We can see this in the countless categories of magazines one can find: women's health, men's interests, gardening, home improvement, cooking, business, fashion, etc. This is even more exaggerated when one takes into account pervasiveness and variety of advertisements that can be found in such magazines that are already geared toward specific interests.

Consumption has changed as well in the last century in a parallel manner moving toward the individual. In the industrial era products were produced on a mass scale. These types of products were made for anonymous clients everyone purchased the same thing. Now, in the post-industrial era, consumers exert more influence, have personalities, and want more variable products. Producers have heard these demands and production has changed to be geared more towards personalized items that can show individual personalities. The passage from this earlier industrial society to the more modern post-industrial society is tied to the idea of these changes in production.

Modern consumerism, brought on by social change and specifically consumer behavior has created an environment for the concept of brand personality to develop. The process by which a brand builds it's platform, or its identity consists of logos, trademarks, personality, marketing communication, consumer confidence, positioning. In marketing, brand personality is used for the aim of positioning which is a strategy where brands emphasize certain distinguishing features or qualities of the brand in order to position itself in the mind of the consumer among other competing brands. All of this is ultimately achieved through advertising. Through this process the brand's platform, essentially becomes its "personality" in the eyes of the consumer.

Each brand has specific features or attributes associated with itself that the consumer relates to: this is why the consumer chooses one brand over another, because they relate to these qualities and they themselves either believe they have these qualities or desire these qualities. A simple example with which we are probably all familiar are the golden arches of McDonald's. The golden " $\mathrm{M}$ " towering high above other bill boards has become a beacon for weary drivers and travelers who know that McDonald's is a quick place where they can stop to eat and rest before they get back on the road. In this way, McDon- 
ald's has used its giant $\mathrm{M}$ to lure in customers off the road, promising them something better than what the other billboards have to offer.

The company ultimately wants their consumers to be so strongly aligned with their brand that the customers will not leave because they will not settle for "inferior" products made or distributed by other brands. These extremely personalized and specific products that the consumers identify with work as a glue that keeps the consumer "stuck" to the company or the brand. Once the consumer has aligned them self with a brand in this way, the consumer allows the brand to begin to think for them. We could go so far as to say that the brand's personality becomes their personality.

Well-known, or strong brands, with personalized products are able to achieve a loyal customer base because, their brands features stand out from among other brands. This at least is what the brands want the consumers to believe and some certainly do. These brands make you believe that you will gain certain benefits from their products which make the consumer feel more important, desirable, smart, etc. There are universal qualities of brand personality that we can also assign as human characteristics. We can see this in the example of Wrangler's marketing campaign "We Are Animals." Wrangler has an association with cowboys and brings to mind the national symbol and legend of the "wild west." In addition even the name, itself comes from this concept, a wrangler, being an actual cowboy or someone who herds cattle. Their campaign "We Are Animals" references those primal, animal instincts that are innate in all humans, and relates them to the quality of ruggedness, or roughness. The campaign aims to win over the consumer by appealing to their emotions and showing that the brand is associated with certain qualities: wildness, strength and resilience, naturalness, activeness. The campaign shows the company as a dynamic brand that can hold up in extreme environments. Using this method, the company makes the consumer think that they will gain these same qualities they see in the product if they purchase it. In this way, brands appeal to the personal values of the consumers, and even to groups of people who share similar values or personalities.

Research done by Plummer (1984), McEnall, De Chernatony Levy (1959) and Furnier (1998) has shown the potential for brand personality to communicate to customers through the use of emotion. Personification and personalization are processes phenomena we can see in the education system, however they are not always fully realized. Both these phenomena have a function in school as well as inn advertising. The function in advertising is to sell 
products, whereas in school the function is to sell education and life skills to students. Advertising is easy - you pay money and get the products, but in education and life reaping benefits is more difficult. You have to sit down and study, put in hard work in order to see the results. Emotion is important in education because brands can become an authority in the same way as a teacher is an authority figure. The way they do this is because through their advertising and marketing campaigns, companies use and play to consumer's emotions Young people want things that they see and perceive as being important for them.

Popular culture is characterized by constantly changing technologies. Things become outdated very quickly. The medium by which information is disseminated has rapidly been changing from paper media to electronic media. This includes both news media, and marketing media. One could argue that the current modern lifestyle has created an atmosphere in which things like consumerism and brand personalities have become values in ways that they did not use to be. In the same way that lifestyle magazines and changes in music and media have spurred personal preferences, desires, and ideas, brand personality can take the role of an authority in consumers especially in adolescents. In modern society, priority and weight is given to pop culture and to consumption of products and because of this, in the world of education and in the minds of students, teachers may take a back seat to the media and marketing tactics. Advertising campaigns allow companies and brands to provide values for students that more traditional values use to fill such as family, education, religion, etc.

Adolescent students are at an age where their personalities are in flux and are still being molded. They are at a place where they are very influenced by the world around them. In today's society, this means their personalities and ideas can be easily shaped by both the media, and popular culture in general. Young people take values they find in the media surrounding them, and create their own version or make them their own. For young people, the media, whether it be advertising, news, social media, or even music can become an authority. As a consequence of this, these medias can motivate adolescents in their decision-making, not only as consumers, but in making decisions about themselves and their world views.

Adolescents express themselves through the brands that they support. By having a selection of many brands and companies to choose from they get to select the personal qualities that they desire. The features of the products that 
they see, they are able to ask such questions as: Is this product for me? What is the reason I am choosing this product over another? How many qualities of this product express me? How many qualities of myself can I find in the product that I'm choosing? In choosing the brand that gives them the most qualities that they deem valuable, these students feel good about themselves.

As previously stated, logos become the identifying feature of a brand that the consumer sees and identifies with. The logo is the "glue" of the relationship between the customer and the brand and adolescents identify themselves so strongly with certain logos almost in the way the might identify with their own initials. However these logos contain embedded values that adolescents don't always think about or consciously notice, but subconsciously these companies and logos are molding these student's values. Similarly, adolescents looking for an authority and desiring specific goals or attributes see products with features conveying the attributes they desire or qualities of social group they want to be associated with, and they count on the fact that if they buy or use these products they will gain the benefits. In this way brands can become an authority for young adults during their formative years when they are still creating their own personalities.

Students, in picking a certain brand, choose qualities that are close to themselves, and that they identify with. Through doing this they are aligning their own personal values and qualities with those of the brands, in this way the brand becomes the students own personal identity. It's at this moment that the student comes into contact with the brand personality. Once the adolescents have aligned themselves with a brand, they begins to allow the brand to think for them. The brand's personality becomes their personality. The brand unknowingly becomes an element of the education process, because the brand, for these young adults, fills the role of an authority. The fact that the brands becomes an authority, is a consequence of the concept of brand personality, and by becoming an authority, the brand semi-fulfills the role of the teacher.

Friendship is a powerful thing, but it plays a significant role in the lives of adolescents. Children, adolescents, and teenagers have a strong need for friendships. Young people want to be perceived by others the way that they see themselves. During this age, adolescents are extremely affected by the need for affirmation. Having a positive vision of themselves allows them to attract around them the type of people with whom they want to spend their time. The development of self-awareness and expression is a transitional phase through which everyone goes. Friendships and peer groups during this time help ado- 
lescents shape their own identities and find their niche in the social climate around them. In this way, interpersonal relationships at this time of life affect the individual's emotional climate. It is apparent that adolescents have more confidence and trust within their peer group than with parents, teachers, and other authority figures. This is because within their own social group they are, for the most part, having similar experiences and can be more open with one another and relate to one another in ways they can't relate to with adults. The assets of a company undoubtedly are used to affect our emotions of how we perceive a company both directly and indirectly and ultimately either positively or negatively.

It is worth nothing that the external factors that can exert an influence on the consumptive behavior affect not only adolescents but their adult parents as well. Today in our modern world with technological tools and a heightened awareness of these things, it is possible to avoid this phenomenon. It is extremely important for teachers to express this to their students in the earliest stages of their education in kindergarten and preschool. The best ways in which teachers to instill these types of values is through play learning. Interacting with the children in various situations allow them to create their own beliefs and ideas. For example, teachers and adults can create make believe situations and games where the children must undertake some kind of decision that is not necessarily portrayed like it would be in the real world. It's important to show how companies try to identify with adolescents and that this has both a good side and a bad side. There is a single objective: the company wants to conform to the expectations of the adolescents. In order to do this it has to establish credibility in a particular way. You can see this in the example of the ad campaign put out by Polkomtel for the brand "PLUSH." The brand is geared toward people ages 16-24, who use pre-paid cellphone services. The tagline for the brand is "No consequences." The company is aiming to appeal to people in this market by showing them that they will have the freedom to talk and text with no limits if they choose this brand. Looking at this ad campaign, we can see that the target audience is one that does not concern themselves with the consequences of their actions. The brand hero that this cell phone company uses is a stuffed bear who is positioned in the ads like a king. This brings to mind a hedonistic lifestyle and the pleasures of a life with no consequences. On one hand ... anthropomorphizing this comedic hero, on the other hand the Because these kinds of values are constantly conveyed through advertisements: on billboards in the city, coupons sent to your email address, etc. the 
kind of behavior portrayed in these ads becomes more acceptable. In turn, as adults respond to ads, the behavior becomes more ingrained. In this way, adolescents can interpret both figuratively and literally.

This phenomenon is truly a challenge for teachers, however it is also an opportunity for teachers to engage with students and connect with them on such universal values as kindness, friendship, compassion and generosity. The short cycle of production and technological changes means that things are changing constantly and every time there is a new advancement, especially in merchandise, this creates a new "need" for the students, one which they may not have even known existed before the creation of the new product. Teachers can't anticipate such needs and this is a hard situation for them. However, teachers should take this as an opportunity, and rather than getting caught up in the specific "needs" as defined by the latest technology, they should address the concept in general.

Teachers need to understand that companies and brands have seeped into the fabric of adolescent upbringing, for better or for worse and are here to stay. Teachers need to be role models for the students and understand that this is an important an inevitable phenomena for adolescents in today's world. Rather than fighting this, they should seek to understand why it is that the students associate with these things and try to engage them in similar ways. In the way that brands show of their qualities through advertising teachers should attempt to find ways for their values to appear just as enticing. The responsibility of teachers is to encourage students to explore for themselves, and to be open minded, not just to believe what they see and hear.

The intention of this paper is to show that this phenomenon exists and needs to be taken into consideration by teachers. Ultimately this concept should be further studied.

\section{REFERENCES:}

AAKER, J.L. (1997), Dimensions of Brand Personality, "Journal of Marketing Research", 34.

CHERNATONY, de L. (2003), Marka. Wizja i tworzenie marki, Gdańskie Wydawnictwo Psychologiczne, Gdańsk. 
CHLEWIŃSKI, Z. (1987), Postawy a cechy osobowości, Towarzystwo Naukowe KUL, Lublin.

DOLIŃSKI, D. (2003), Psychologiczne mechanizmy reklamy, Gdańskie Wydawnictwo Psychologiczne, Gdańsk.

EKEL, J., Jaroszyński, J., Ostaszewska, J. (1965), Mały słownik psychologiczny, Wiedza Powszechna, Warszawa.

FALKOWSKI, A., Tyszka, T. (2009), Psychologia zachowań konsumenckich, Gdańskie Wydawnictwo Psychologiczne, Gdańsk.

FISKE, J. (1999), Wprowadzenie do badań nad komunikowaniem, Astrum, Wrocław. GRZEGORCZYK, A. (2005), Instrumenty ksztattowania wizerunku marki, Wyższa Szkoła Promocji w Warszawie, Warszawa.

HALL, C.S., Lindzey, C. (2010), Teorie osobowości, PWN, Warszawa.

KALL, J. (2004), Silna Marka. Istota i kreowanie, Polskie Wydawnictwo Ekonomiczne, Warszawa.

PATKOWSKI, P. (2010), Potencjat konkurencyjny marki, POLTEXT, Warszawa.

PLUMMER, T.J. (1984), How Personality makes a difference, "Journal of Advertising Research".

MCCRAE, R. Costa, P.T. (2005), Osobowość dorostego człowieka: perspektywa teorii pięcioczynnikowej, Wydawnictwo WAM, Kraków.

SIEK, S. (1986), Struktura osobowości, Akademia Teologii Katolickiej, Warszawa. SPERLING, A.P. (1995), Psychologia, Zysk i S-ka, Poznań.

STRelaU, J. (2000), Osobowość jako zespót cech, [w:] Psychologia. Podręcznik Akademicki, t. 2, Gdańskie Wydawnictwo Pedagogiczne, Gdańsk.

UPSCHAW, L.B. (1995), Building Brand Identity, John Wiley \& Sons. 